\title{
Defining a mid-Holocene earthquake through speleoseismological and independent data: implications for the outer Central Apennines (Italy) seismotectonic framework
}

\author{
Alessandra Di Domenica and Alberto Pizzi \\ Department of Engineering and Geology, University G. d'Annunzio, Via dei Vestini 31, Chieti, 66013, Italy \\ Correspondence to: Alessandra Di Domenica (a.didomenica@unich.it)
}

Received: 16 May 2016 - Discussion started: 27 June 2016

Revised: 12 January 2017 - Accepted: 16 January 2017 - Published: 10 February 2017

\begin{abstract}
A speleoseismological study has been conducted in the Cavallone Cave, located in the easternmost carbonate sector of the Central Apennines (Maiella Massif), in a seismically active region interposed between the post-orogenic extensional domain, to the west, and the contractional one, to the east. The occurrence of active "silent normal faults", to the west, close to blind thrusts, to the east, raises critical questions about the seismic hazard for this transitional zone. Large collapses of cave ceilings, fractures, broken speleothems with new re-growing stalagmites on their top, preferential orientation of fallen stalagmites and the absence of thin and long concretions have been observed in many portions of the karst conduit. This may indicate that the cave suffered sudden deformation events likely linked to the occurrence of past strong earthquakes. Radiocarbon dating and, above all, the robust correspondence with other coeval on-fault and off-fault geological data collected in surrounding areas outside the cave, provide important constraints for the individuation of a mid-Holocene paleoearthquake around 4.6-4.8 kyr BP. On the basis of the available paleoseismological data, possible seismogenic sources can be identified with the Sulmona normal fault and other active normal fault segments along its southern prosecution, which recorded synchronous strong paleoevents. Although the correlation between speleotectonic observations and quantitative modeling is disputed, studies on possible effects of earthquake on karstic landforms and features, when corroborated by independent data collected outside caves, can provide a useful contribution in discovering past earthquakes.
\end{abstract}

\section{Introduction}

In highly seismically active regions characterized by karst environments, where the identification and characterization of the seismogenic sources are not strictly constrained by both geological and seismological data, speleoseismology (i.e., the investigation of traces of past earthquakes in caves) represents a potential tool for the improvement of the seismological record and to better understand the seismotectonic framework and seismic hazard of an area. Cave environments can contain a great amount of well-preserved geological information and are ideal for paleoseismological investigations because earthquake damages can be fossilized by post-earthquake calcification and thus preserved from erosion.

Following some pioneering studies at the beginning of the 1990s (see Becker et al., 2006, for a review), many works have focused on the significance of cave damages and their possible correlations with active tectonics and, in particular, with the effects of seismic shaking. This evidence includes broken speleothems and fallen stalactites (e.g., Postpischl et al., 1991; Ferranti et al., 1997; Lemeille et al., 1999; Delaby, 2001; Kagan et al., 2005; Šebela, 2008; Panno et al., 2009; Bábek et al., 2015; Méjean et al., 2015), blocks and ceiling collapses (e.g., Gilli, 1999; Pérez-López et al., 2009), deformed cave sediments and fault displacements (e.g., Gilli et al., 2010; Bábek et al., 2015), and speleothem growth anomalies (e.g., Forti et al., 1981; Forti and Postpischl, 1984; Akgöz and Eren, 2015; Rajendran et al., 2015). Although direct observations of cave damages immediately after an earthquake have rarely been observed, "seismothems" (i.e., speleothems potentially broken, or deformed, by a seismic 
event; Delaby, 2001) have been increasingly recognized in many caves worldwide, allowing researchers to discover past earthquakes (see Becker et al., 2006, for a review). On the other hand, robust evidence and correlations of specific paleoearthquakes in caves with other independent paleoseismic records are very rare in the literature (Becker et al., 2005).

The analysis of seismothems requires a careful and integrated study approach aimed at the recognition of peculiar structures through the observation of speleothem morphologies. Several typical features can be referred to tectonic coseismic shaking (Forti, 2001). The most characteristic is represented by stalagmites cut along sub-horizontal planes, with the upper parts only translated from their original position but still standing upright or toppled and lying on the floor close to their base, accompanied with new-growing stalagmites covering the rupture surface of the stump (e.g., Postpischl et al., 1991; Delaby, 2001; Kagan et al., 2005). The geometries of the fallen part and the stump must match, allowing the reconstruction of the original speleothem. Another piece of evidence of earthquake-induced phenomena is the presence of specific spatial distribution patterns of fallen concretions, resting on sub-horizontal or slightly inclined cave ground. Collapsed stalagmites toward preferential orientations may be consistent with the strike of the earthquake source (e.g., Gilli et al., 1999; Ferranti et al., 2015) or its slip direction (e.g., Méjean et al., 2015). More suitable for this kind of observations are fallen stalagmites cemented on the floor to ensure that broken speleothems have maintained their original direction in time (Forti, 2001). These observations have to be strengthened by dating in order to find correlations with past earthquakes. To constrain the age of the damaging event it is necessary to date the oldest layer at the base of the regrowth stalagmite and the youngest layer at the tip of the fallen stalagmite (e.g., Postpischl et al., 1991; Forti, 2001; Kagan et al., 2005). Statistical analyses and comparison with other data (e.g., paleoseismological data collected along neighboring seismogenic sources) are crucial to better constrain the age of a paleoearthquake. On the other hand, seismothems-like features can be induced also by non-seismic processes such as human and animal presence, shocks due to mine blasting, cryogenic fracturing, gravitational collapses, creep movements of sediments, glacial intrusion and catastrophic floods (e.g., Gilli, 2005; Becker et al., 2012). Therefore, it is fundamental to consider more factors that can interact and rule out all other possible nonseismic causative processes.

Finally, the correlation between field observations and quantitative modeling is disputed. Some authors state that high accelerations are needed to break speleothems and that only thin and long concretions can be damaged following seismic shaking due to "reasonably" strong earthquake $\left(3 \mathrm{~m} \mathrm{~s}^{-2}<\right.$ PGA $<10 \mathrm{~m} \mathrm{~s}^{-2}$ ) (e.g., Cadorin et al., 2001; Lacave et al., 2000, 2004, 2012). Nevertheless, field evidence cannot be neglected and suggests that empirical mechanical relations are possibly lacking for considering some significant parameters and conditions (Delaby, 2001).

Due to the uncertainties affecting this method of analysis, it is fundamental to combine speleoseismological data with independent paleoseismic records in other geological archives outside caves, such as liquefaction evidence within lake and flood-plain deposits, locations of rock falls and coseismic fault displacements (Becker et al., 2005, 2006).

A few speleotectonic studies have been conducted in the high seismically active region of the Apennines (Forti and Postpischl, 1984; Postpischl et al., 1991; Ferranti et al., 1997, 2015). We performed a geological-structural field study, with a paleoseismological approach, in the Cavallone Cave located within the Maiella Massif, in the eastern Central Apennines (Fig. 1). The aim was to find typical earthquakerelated structures and, then, to improve the paleoseismological record and characterization of the seismogenic sources affecting a complex seismotectonic region such as the easternmost sector of the Central Apennines. The evidence described in this work suggests that the conduit underwent repeated earthquake damages in the past. Radiocarbon dating provided important constraints for the individuation of a paleoearthquake, and an exceptional geological record available from surrounding areas allowed for robust correlation of the recognized paleoearthquake with other independent data (i.e., paleoseismological and geological data outside the cave), strengthening the reliability of speleoseismological studies in discovering past earthquakes.

\section{Geological and structural setting}

The Apennines are a Neogene-Quaternary foreland-verging fold-and-thrust belt, showing a complex structural arrangement derived from the interaction between contractional structures and pre-existing extensional faults (e.g., Coward et al., 1999; Scisciani et al., 2002; Tozer et al., 2002; Butler et al., 2006; Calamita et al., 2011; Scisciani, 2009; Di Domenica et al., 2014a, b; Pace et al., 2014; Cardello and Doglioni, 2015). The orogenesis involved Triassic-toMiocene sedimentary successions related to different basin and platform paleogeographic domains of the Adria Mesozoic paleomargin (e.g., Ciarapica and Passeri, 2002; Patacca and Scandone, 2007). Post-orogenic extension affects the Apennine chain and is responsible for present-day seismicity especially concentrated within the axial part of the belt. Major seismicity is related to NW-SE-trending, 15 to $30 \mathrm{~km}$ long Quaternary normal fault systems which are compartmentalized by Neogene regional oblique NNE-SSWtrending thrust ramps acting as "persistent structural barriers" and controlling the along-strike normal fault systems propagation and segmentation (Fig. 1; e.g., Tavarnelli et al., 2004; Pizzi and Galadini, 2009; Di Domenica et al., 2012). The NW-SE-trending active normal fault systems are responsible for high-magnitude destructive earthquakes 


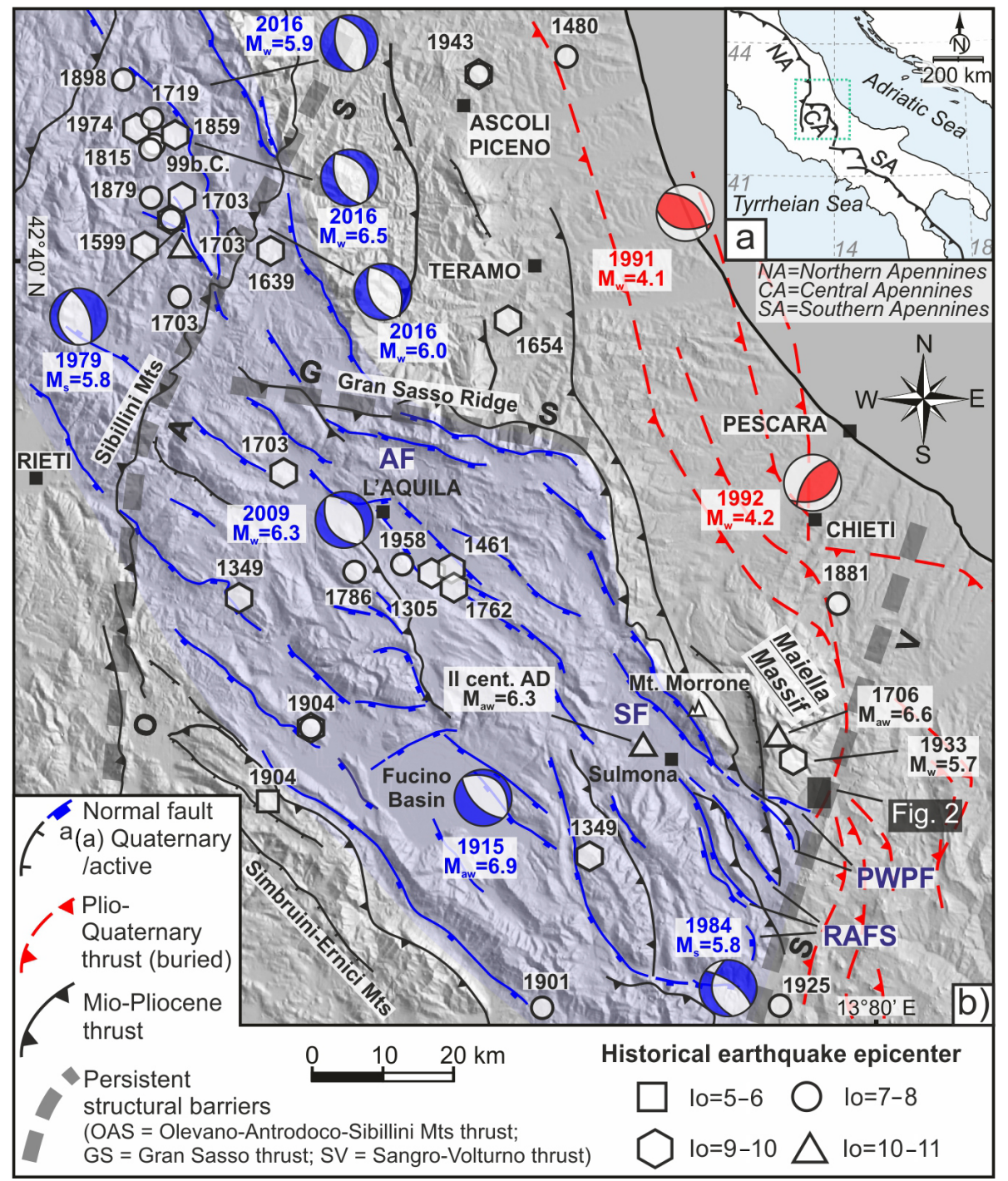

Figure 1. (a) The three major arcs of the Apennine Neogene chain. (b) Simplified structural map of the Central Apennines and related seismicity (modified from Pizzi et al., 2010; de Nardis et al., 2011). Within the axial zone of the chain major Quaternary/active post-orogenic normal faults, superposed onto the Neogene thrusts, define the intra-Apennine extensional domain (light-blue band). Contractional or strikeslip tectonics prevail in the Adriatic foreland area, to the east. Epicenter location and macroseismic intensity (Io), or equivalent moment magnitude $\left(M_{\mathrm{aw}}\right)$ and moment magnitude $\left(M_{\mathrm{W}}\right)$, of historical and recent earthquakes (Working Group CPTI, 2004; Rovida et al., 2011 and Ceccaroni et al., 2009 for the 2 nd century AD earthquake) indicate stronger seismicity within the inner extensional domain and only moderate events in the outer contractional zone. Some events, such as those in 1706 and 1933, localized in the Maiella Massif (i.e., at the extension/contraction transitional domain), still have an uncertain source and kinematics. Persistent structural barriers (dotted grey bands), oblique to the main trend of the normal fault systems, control the propagation and segmentation of the Quaternary/active normal faults (Pizzi and Galadini, 2009). AF: Assergi Fault; SF: Sulmona Fault; PWPF: Palena-western Porrara fault system; RAFS: Rotella-Aremogna fault system.

( $M \leq 7$; e.g., Calamita and Pizzi, 1994; Ghisetti and Vezzani, 1999; Galadini and Galli, 2000; Working Group CPTI, 2004; Rovida et al., 2011). On the other hand, so-called "silent faults" characterize the easternmost alignment of the Central Apennine normal fault systems (e.g., Sulmona Fault, Assergi Fault; Fig. 1). No large-magnitude historical seismic events can be strictly related to these structures which, however, show evidence of late Pleistocene-Holocene activity (Barchi et al., 2000; Galadini and Galli, 2000; Papanikolaou et al., 2005 , and references therein). Only recently has the 2 nd century $\mathrm{AD}$ earthquake that occurred in central Italy been associated with the Sulmona fault system through archaeoseismological and paleoseismological evidence (Ceccaroni et al., 2009; Galli et al., 2015). This lack of data could be due to long recurrence intervals (1400-2600 years; Galadini and Galli, 2000) and/or to the incompleteness of the available 


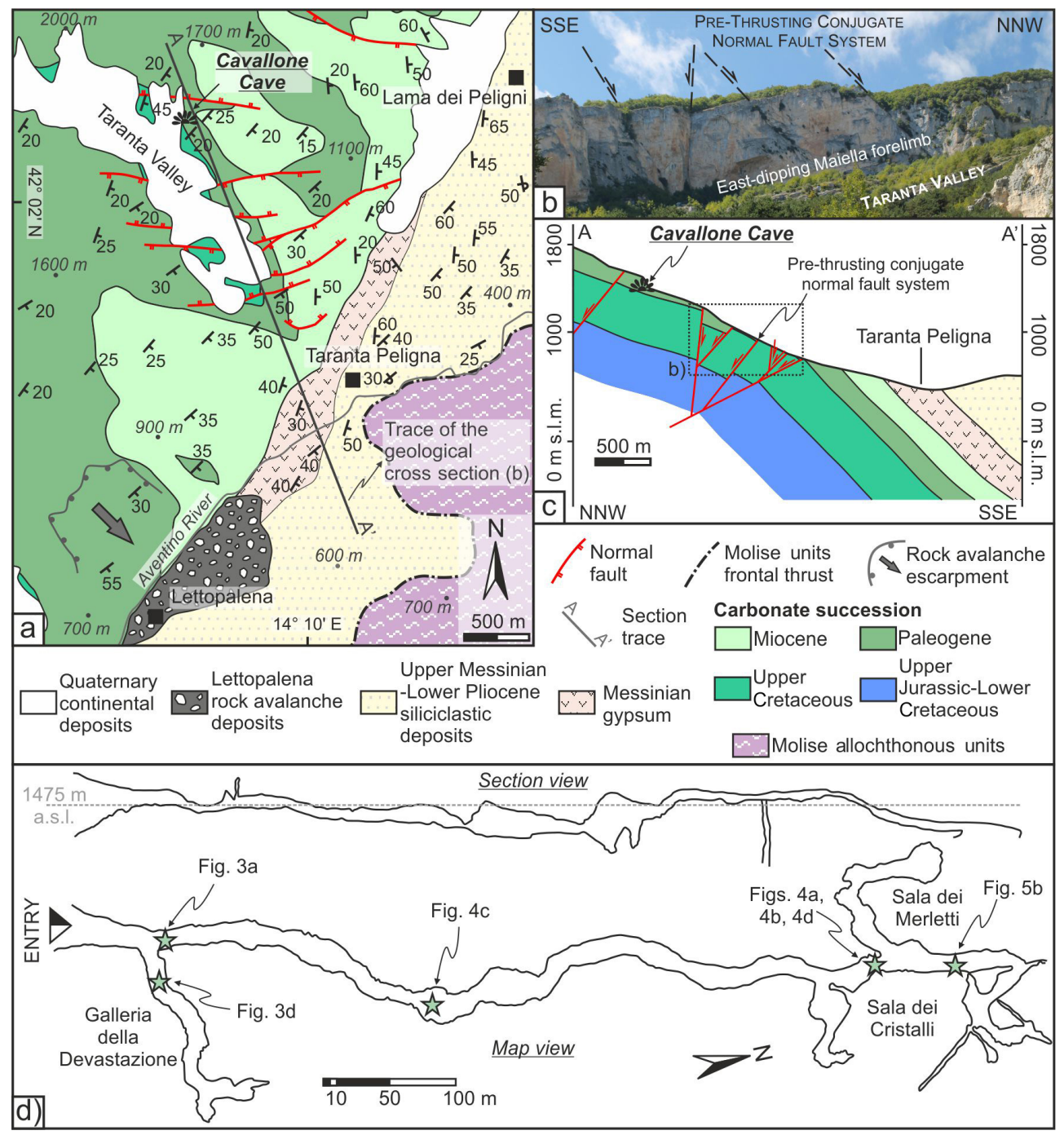

Figure 2. Schematic geological map of the study area (a) (simplified from Accotto et al., 2014; see Fig. 1 for the location) and geological cross section along the Taranta Valley (c) showing SE-dipping Meso-Cenozoic carbonates, passing to Mio-Pliocene gypsum and siliciclastic deposits, describing the forelimb of the Maiella anticline. E-W-trending normal faults represent pre-thrusting conjugate normal fault systems (b). The Cavallone Cave is located along the cliffs of the Taranta Valley, in the southeastern portion of the Maiella Massif; to the south, the village of Lettopalena is situated on top of rock avalanche deposits. (d) Section and map views of the Cavallone Cave showing the articulate morphology of the cave ground.

historical seismic catalogues (e.g., Stucchi et al., 2004), suggesting high seismic hazard levels and raising critical questions about the identification of the seismogenic structures and the true seismic potential of these areas. This has unfortunately been confirmed by the recent August-October 2016 seismic sequence that struck central Italy and that was related to the activation of the Mt. Vettore-Mt. Bove normal fault system (Fig. 1), which had previously been considered "silent" (Galadini and Galli, 2003), although already identified in the field and mapped as an active fault (Pizzi, 1992; Pizzi et al., 2002; Calamita and Pizzi, 1992, 1994; Calamita et al., 1992). The seismotectonic framework of the CentralNorthern Apennines is complicated by the occurrence of re- verse and strike-slip events delineating an active contractional domain along the peri-Adriatic foredeep-foreland sector that exhibits a moderate and less frequent seismicity with respect to the western extensional one and for which paleoseismological and seismological data are very scarce (Fig. 1; e.g., Frepoli and Amato, 1997; Pondrelli et al., 2006; Montone et al., 2012).

The Cavallone Cave entrance is located at $1475 \mathrm{~m}$ a.s.l., in the Taranta Valley, a NNW-SSE/NW-SE-trending incision cutting through the Maiella Massif forelimb (Figs. 1 and 2). The Maiella Massif represents the outermost outcropping carbonate anticline of the Central Apennines, involving Early Cretaceous-Miocene carbonate platform and 
slope-basin successions (e.g., Donzelli, 1969; Patacca and Scandone, 1989; Festa et al., 2014, and references therein). The Maiella anticline is related to the emplacement of a Pliocene-early Pleistocene NW-SE/NNE-SSW-trending curved frontal thrust, buried beneath Mio-Pliocene siliciclastic deposits and Molise allochthonous Units (e.g., Scisciani et al., 2002; Pizzi, 2003). Along the Taranta Valley the Paleocene-upper Oligocene carbonate ramp succession is spectacularly exposed and results affected by E-W prethrusting conjugate normal fault systems (Fig. 2; Scisciani et al., 2000; Festa et al., 2014).

Given the seismotectonic framework described above, it is clear how the Maiella Massif is interposed between two distinct domains: extensional, to the west, and contractional, to the east (Fig. 1). Although the Sulmona-Maiella area represents the epicentral zone of high-magnitude historical earthquakes, such as those that occurred in the 2nd century AD $\left(M_{\mathrm{aw}}=6.3\right)$, in $1706\left(M_{\mathrm{aw}}=6.6\right)$ and in $1933\left(M_{\mathrm{w}}=5.7\right.$; Working Group CPTI, 2004; Rovida et al., 2011), the identification of the seismogenic source(s) responsible for this seismic activity is poorly constrained (by both geological and seismological data) and still debated. The most hazardous adjacent seismogenic structures are the Sulmona normal fault (or Mt. Morrone fault) capable of producing $M=6.6-6.7$ earthquakes (e.g., Vittori et al., 1995; Galadini and Galli, 2000; Gori et al., 2011, 2014; Galli et al., 2015), the RotellaAremogna normal fault system and the Palena-western Porrara normal fault system (Fig. 1). Late Quaternary evidence of faulting have been described for the latter fault system (Pizzi et al., 2010), while paleoseismological studies allowed for four faulting events to be recognized in the past $\sim 9 \mathrm{kyr}$ along the Sulmona Fault (Galli et al., 2015). Paleoearthquakes have also been identified along different segments of the Rotella-Aremogna normal fault system (Frezzotti and Giraudi, 1989; Calderoni et al., 1990; Brunamonte et al., 1991; D’Addezio et al., 2001; Tesson et al., 2016; Fig. 1). Regarding the frontal area of this sector of the chain, few seismological data are available and seismicity could be probably associated with buried Apennine thrust fronts (e.g., Scisciani and Calamita, 2009; de Nardis et al., 2011; DISS Working Group, 2015) such as those activated in the Northern Apennines during the 2012 Emilia Romagna earthquake (e.g., Pizzi and Scisciani, 2012; Govoni et al., 2014, and references therein).

\section{Method}

We performed a careful structural-geological analysis along the main conduit and some lateral branches of the Cavallone Cave (Fig. 2), for a total length of ca. $1 \mathrm{~km}$. The Cavallone Cave has been exposed to human presence since the end of the 1600 s and ca. $500 \mathrm{~m}$ of it is now open for touristic purposes. In the vicinity of the cave entrance and along the touristic path, broken stalagmites may be related to human depredation. Nevertheless, there are portions of the cave, far enough from the entrance and from the touristic path, which allow for excluding the presence of humans and animals in the past that might have altered the karstic landforms and features of the cave (rooms "Sala dei Cristalli" and "Sala dei Merletti" in Fig. 2d). For the speleotectonic analysis, considerable attention has been paid to distinguishing the features described in the literature as earthquake-related structures (e.g., stalagmites cut along sub-horizontal planes, with the upper part lying close to their base and cemented on the floor), according to the indications of Forti (2001). Measurements of fall directions, dimensions of speleothems and distribution of speleothem fracturing were collected in the sectors of the cave considered suitable for the study, far enough from possible human disturbance. Only broken stalagmites lying and cemented on sub-horizontal or slightly inclined cave ground have been considered for the statistical analysis of the representative azimuths of fall directions. Careful observations have also been made to eliminate other causes for speleothem damage. For a detailed paleoseismic interpretation, accelerator mass spectrometry (AMS) radiocarbon dating of the damaged speleothems and of a fragment of a tree involved in a rock avalanche adjacent to the cave have been performed (by Beta Analytic Radiocarbon Dating Laboratory, Florida, USA).

\section{Speleoseismological analysis}

The Cavallone Cave mainly develops in a $\mathrm{N}-\mathrm{S}$ direction within the Paleocene-upper Oligocene calcarenite and cherty limestone of the Maiella carbonate ramp succession (Fig. 2). Within the cave, patches of both fine- and coarse-grained deposits are preserved. In the majority of cases, these latter represent collapsed material over which new generations of concretions have grown up. The cave shows many concretions, especially stalagmites. Near the entrance, the largest stalagmites (more than $2 \mathrm{~m}$ high) are preserved. An exposed longitudinal section of one of these speleothems shows that the concretion grew onto a ca. $2 \mathrm{~m}$ thick pile of chaotic material (likely originated from repeated collapse events), involving a large portion of stalagmites and draped by flowstone deposits (Fig. 3a, b and c). Large stalagmites (more than $3 \mathrm{~m}$ high, with diameter of $30-50 \mathrm{~cm}$ ) are also preserved within the first eastern branch of the cave named "Galleria della Devastazione", which cannot be visited by tourists (Fig. 2d). Here stalagmites rest tilted converging toward the central axis of the conduit, and some of them are broken (Fig. 3d). The stalagmites located at the entrance of the cave and in the Galleria della Devastazione branch are the largest observed in the cave, indicating that they probably represent the oldest preserved speleothems. Evidence of falls and collapses, moreover, shows that the cave underwent several sudden deformation events (probably of different origin) during its development. Nevertheless, for the Galleria della Devas- 


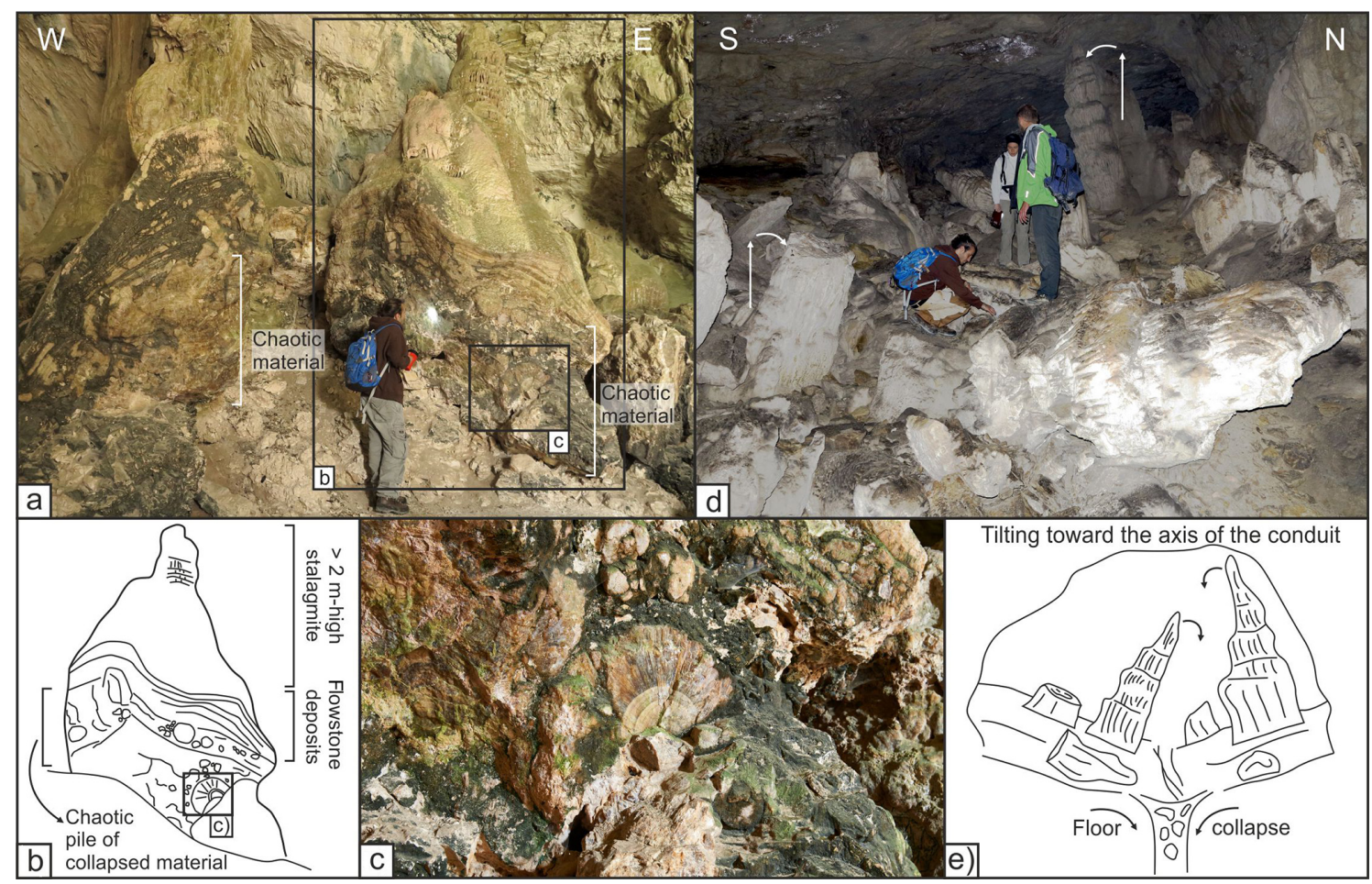

Figure 3. (a) Superposed multiple phases of large collapses and concretions near the entrance of the cave. Meter-scale large stalagmites grew on top of thick piles of chaotic materials, draped by flowstone deposits (sketch of b), within which large portions of concretions tens of centimeters thick are involved (close-up of c). (d) Great collapses involving meter-scale large stalagmites in the "Galleria della Devastazione". Stalagmites still standing upright show a clear tilting toward the axis of the conduit, probably as a consequence of floor sinking (see sketch of e). See Fig. $2 \mathrm{~d}$ for sites location.

tazione branch earthquake-induced damages are difficult to be invoked as the main cause of its present-day configuration, since the strength of the seismic events would have to have been far greater to break such large concretions (e.g., Cadorin et al., 2001; Lacave et al., 2000, 2004, 2012). A strong influence, instead, could have been exerted by gravitational processes that possibly caused the floor to sink (Fig. 3e), probably as a consequence of the collapse of a deeper karst network. However, it cannot be excluded that this collapse could have also been triggered by a strong seismic event.

Apart from these first meters of the cave, stalagmites found in the conduit do not exceed 1 or, exceptionally, $2 \mathrm{~m}$ in height and have diameters ranging between 10 and $30 \mathrm{~cm}$ on average. Intact stalagmites showing these dimensions, however, are very scarce and are preserved only in restricted portions of the conduit, while the most abundant unbroken stalagmites do not exceed $20 \mathrm{~cm}$ in height. Regarding the stalactites, those appearing well developed (more than $1 \mathrm{~m}$ long and with a diameter of about $10 \mathrm{~cm}$ ) result as broken in the majority of cases. On the other hand, where the stalactites are entirely preserved, they show uniform lengths that do not exceed some tens of centimeters (Fig. 4a). From a general point of view, therefore, the Cavallone Cave is lacking intact long and thin speleothems. This raises questions because long and thin concretions are the first to be destroyed during an earthquake and it is generally accepted in the literature that soda straw damages are reliable indicators of coseismic shacking (e.g., Lacave et al., 2004; Becker et al., 2006). Moreover, ceiling collapses are widespread and corroborated by the presence of piles of collapsed materials in many points along the conduit. On top of these piles, small stalagmites, from a few centimeters up to $20 \mathrm{~cm}$ high at most, can be observed (Fig. 4c). Often the floor of the conduit shows centimeter-wide subvertical open fractures that affect concretions (Fig. 4b) and run at the base of the cave walls, probably suggesting the interplay of different processes, from gravitational to seismic.

Especially in the rooms "Sala dei Cristalli" and "Sala dei Merletti" (see Fig. 2d for the location), typical features that are associated in the literature with earthquake damages can be observed. These features are represented by fractured stalagmites showing sub-horizontal cut planes located in the lower third of their height. Where it was possible to observe both the stumps and the fallen portion of the speleothems that underwent these kinds of damages, the concretions show diameters of $10-15 \mathrm{~cm}$ and original lengths of $40-100 \mathrm{~cm}$ on average. The upper parts of these broken speleothems are standing upright, only translated on the fracture plane (Fig. 4d) or have fallen and are cemented on the 


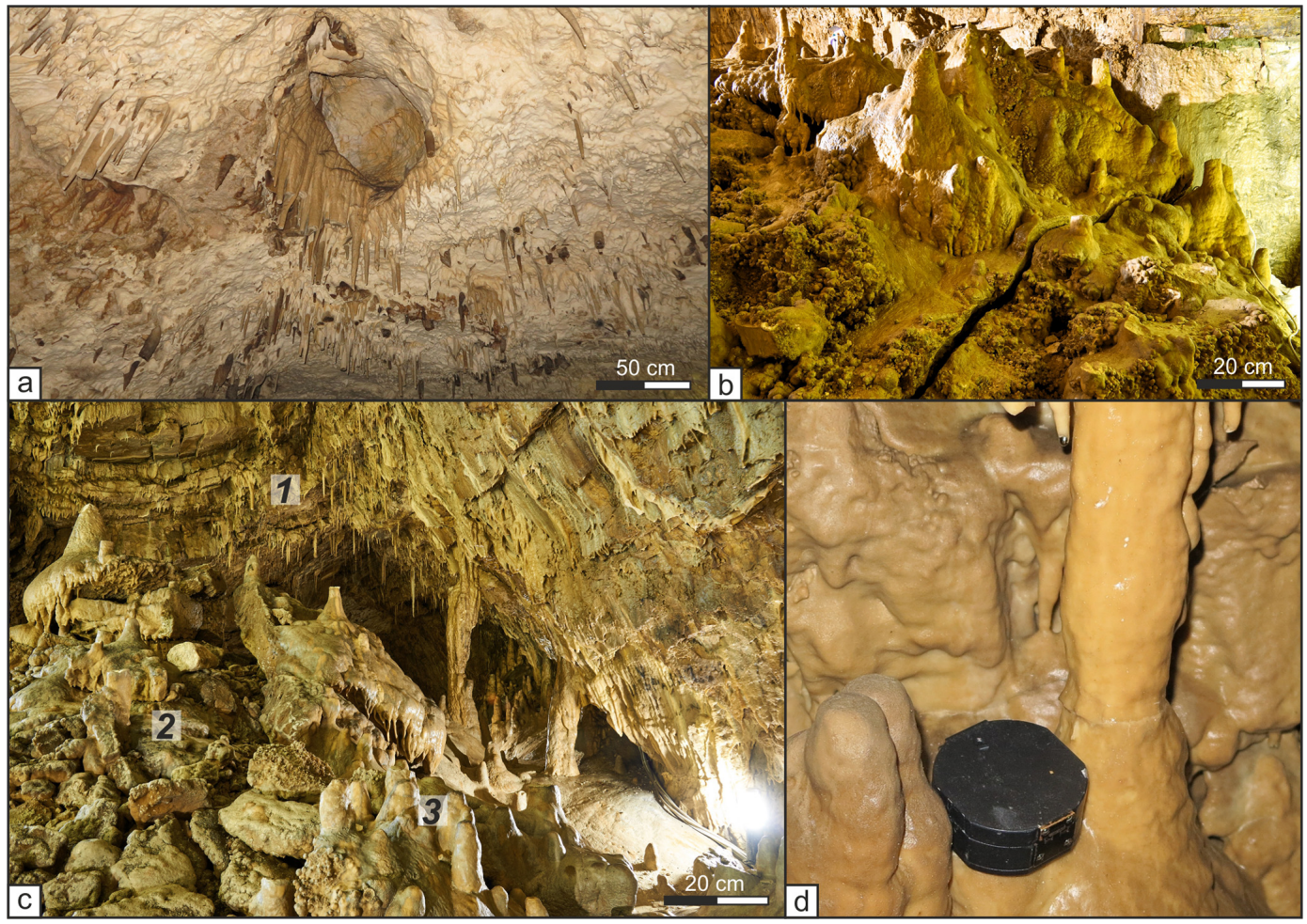

Figure 4. (a) Typical setting of the cave ceilings where originally "long" stalactites (probably more than $1 \mathrm{~m}$ ) are all truncated at the same point. Only short stalactites (tens of centimeters long) are entirely preserved. (b) Centimeter-wide sub-vertical open fractures frequently affecting flowstones, running at the base of the cave walls. (c) Centimeter- to decimeter-high stalagmites growing on top of collapsed materials: (1) ceiling rejuvenated by collapses, (2) blocks from the collapsed ceiling, and (3) stalagmites growth after the ceiling collapse. (d) Speleothem cuts along a sub-horizontal plane, with the upper part only translated from their original position but still standing upright. See Fig. 2d for site locations.

floor (Fig. 5b), lying close to their corresponding stumps. Most of the examples of these stalagmites were found to remain on sub-horizontal or slightly inclined cave ground. The cut planes of the broken speleothems are often covered by new-growing stalagmites, a few centimeters high (2$5 \mathrm{~cm}$ ), similar to those found on top of collapsed materials. The analysis of the orientation of the fallen stalagmites cemented on the floor reveals two preferential trends, NNWSSE and ENE-WSW (Fig. 5a), respectively roughly parallel and perpendicular to the strike of the main seismogenic normal faults in the extensional domain to the west and south of the Maiella Massif (e.g., Sulmona, Rotella-Aremogna and Palena-western Porrara normal fault systems), whereas, to the east, the thrust planes generally strike ca. $\mathrm{N}-\mathrm{S}$ (i.e., parallel to the Sangro-Volturno thrust zone; see Fig. 1). The preferential orientation of broken speleothems has been considered as seismic-related, and has often been found as concordant with the orientation of the seismogenic causative faults (e.g., Delaby, 2001; Forti, 2001; Postpischl et al., 1991; Kagan et al., 2005; Ferranti et al., 2015).

In the cave we found peculiar examples of features similar to that showed in Fig. 5b. The two parts of the broken speleothem perfectly match and a new generation of con- cretion, with dimension analogous to other stalagmites' regrowth on broken speleothems and collapsed materials (2$5 \mathrm{~cm}$ high), can be found on top of the cut plane. A peculiarity of the analyzed concretions is the presence of socalled "macroholes", i.e., millimeter- to centimeter-size cavities which can determine significant secondary porosity of the speleothem (Shtober-Zisu et al., 2012). These holes can develop parallel to the growth axis of the stalagmite ("axial holes"), causing the characteristic antiformal shape of the surrounding growth layers which are bent downward towards the holes (Fig. 6a). The origin of the axial holes has been linked to a syn-depositional slow rate of calcite accumulation and falling-drop erosion. Also, "off-axis holes" can occur and they are related to post-depositional calcite corrosion, possibly controlled by bacterial activity (Shtober-Zisu et al., 2014).

According to the available literature (e.g., Forti, 2001), the speleothem of Fig. 5b can be compared to a "seismothem" (Delaby, 2001); hence, we chose it for our paleoseismological analysis. A sample of the tip of the upper part of the broken stalagmite and a sample of the base of the small stalagmite growing on top of the stump have been collected. The AMS analysis has been performed on the youngest layer of 


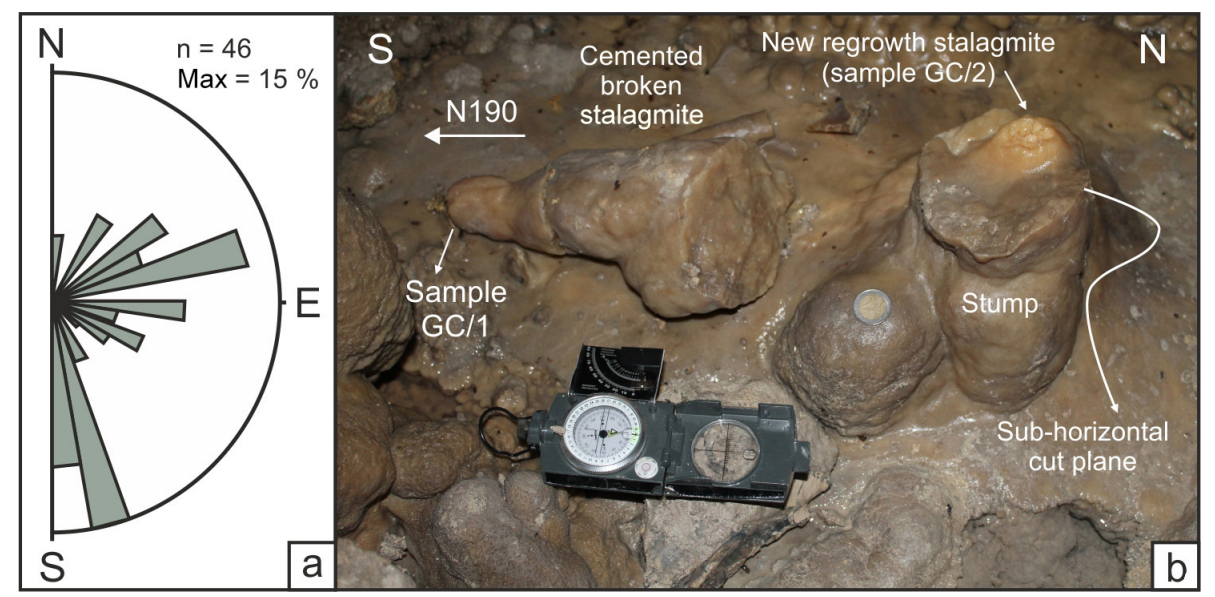

Figure 5. (a) Rose diagram of the measured orientations of fallen stalagmites cemented on the floor. Two main trends can be recognized: ENE-WSW and NNW-SSE, respectively orthogonal and parallel to the main active normal faults of the area. (b) Seismothem-like feature chosen for radiocarbon dating: stalagmite (originally $\sim 40 \mathrm{~cm}$ high) broken along a sub-horizontal plane, fallen toward N190 and resting cemented on the floor (see Fig. $2 \mathrm{~d}$ for the location). On the stump surface a ca. $2 \mathrm{~cm}$ high new stalagmite is growing. "GC/1" and "GC/2" are the codes of the dated samples (see Fig. 6).

Table 1. Results of the radiocarbon dating performed by the Beta Analytic Radiocarbon Dating Laboratory (Florida, USA) on the wood fragment buried within the Lettopalena rock avalanche.

\begin{tabular}{llrr}
\hline Sample & $\begin{array}{l}\text { Laboratory } \\
\text { code }\end{array}$ & $\begin{array}{r}{ }^{14} \mathrm{C} \text { age } \\
(\mathrm{yr} \mathrm{BP})\end{array}$ & $2 \sigma$ cal. 95\% \\
\hline LRA & Beta-444981 & $4610 \pm 30$ & $5445-5385$ yr BP \\
& & & $5325-5300$ yr BP \\
\hline
\end{tabular}

the broken stalagmite (sample "GC/1"; likely pre-seismic) and on the oldest layer of the new-growing stalagmite, as close as possible to its mutual contact with the cut plane of the stump (sample "GC/2"; likely post-seismic; Figs. 5b and $6 \mathrm{a}$ ). The age of the possible paleoearthquake should be more recent than the age of the tip of the broken stalagmite and more ancient than the base of the new stalagmite growing on the stump. The break and the start of the regrowth of the stalagmites should be assumed as instantaneous and simultaneous events. The results of both samples are in fact highly comparable and indicate a time span that extends from 4840 to $4525 \mathrm{yr}$ BP ( $2 \sigma$ cal. age; Fig. $6 \mathrm{~b}$ ). As sample GC/1 belongs to a stalagmite older than sample $\mathrm{GC} / 2$, we can strengthen our chronological constraint considering only the intervals within which the dating of the two samples overlaps. In this way, we obtain that the rupture of the speleothem occurred around $4730 \pm 85 \mathrm{yr}$ BP (Fig. 6c).

\section{Correlation with independent geological records}

In order to validate the possible seismic origin of the broken speleothem we looked for other synchronous and indepen- dent evidence outside the cave, and we found that the result of the radiocarbon dating matches with other geological evidence and data collected in surrounding areas.

A few kilometers south of the Cavallone Cave, the Lettopalena rockslide avalanche deposits outcropping at the base of the Maiella forelimb are of interest (Fig. 2a). The rock mass volume involved is on the order of $10^{6} \mathrm{~m}^{3}$ and includes meter-scale angular-shaped rock blocks, with a sandy matrix, arranged in a chaotic texture and an inverse grading (Paolucci et al., 2001; Di Luzio et al., 2004; Bianchi Fasani et al., 2014). The origin of the Lettopalena rock avalanche has been linked to deep-seated gravitational slope deformation (Di Luzio et al., 2004; Bianchi Fasani et al., 2014) or to earthquake triggering, as initially proposed by Paolucci et al. (2001), who reproduced the rockslide considering a M 5.5 event. Well-preserved buried wood was found within the landslide body. According to specific analyses reported in Paolucci et al. (2001), the fragment belongs to an innerlateral portion of a Quercus ilex trunk that was dated around $4800 \pm 60 \mathrm{yr}$ BP (can be considered a "radiocarbon age", corresponding to ca. 5.3-5.6 kyr BP $2 \sigma$ calibrated age). Due to the importance of this datum, we performed a new radiocarbon dating of the wood sample (preserved at the geological museum in the village of Palena, Italy) obtaining a $2 \sigma$ calibrated age of 5445-5300 yr BP (Table 1), which is hence slightly younger than that of Paolucci et al. (2001). However, considering that the sample comes from the inner part of a long-lived tree (i.e., Quercus ilex, which can often reach the age of 1000; e.g., Pignatti, 1982), it is clear that the obtained age is not that of the rock slide; instead, it simply corresponds to the age of the inner part of the tree. Therefore, it is possible that the rock avalanche could have occurred some hundreds years later than 5445-5300 yr BP (that is, when the tree was 


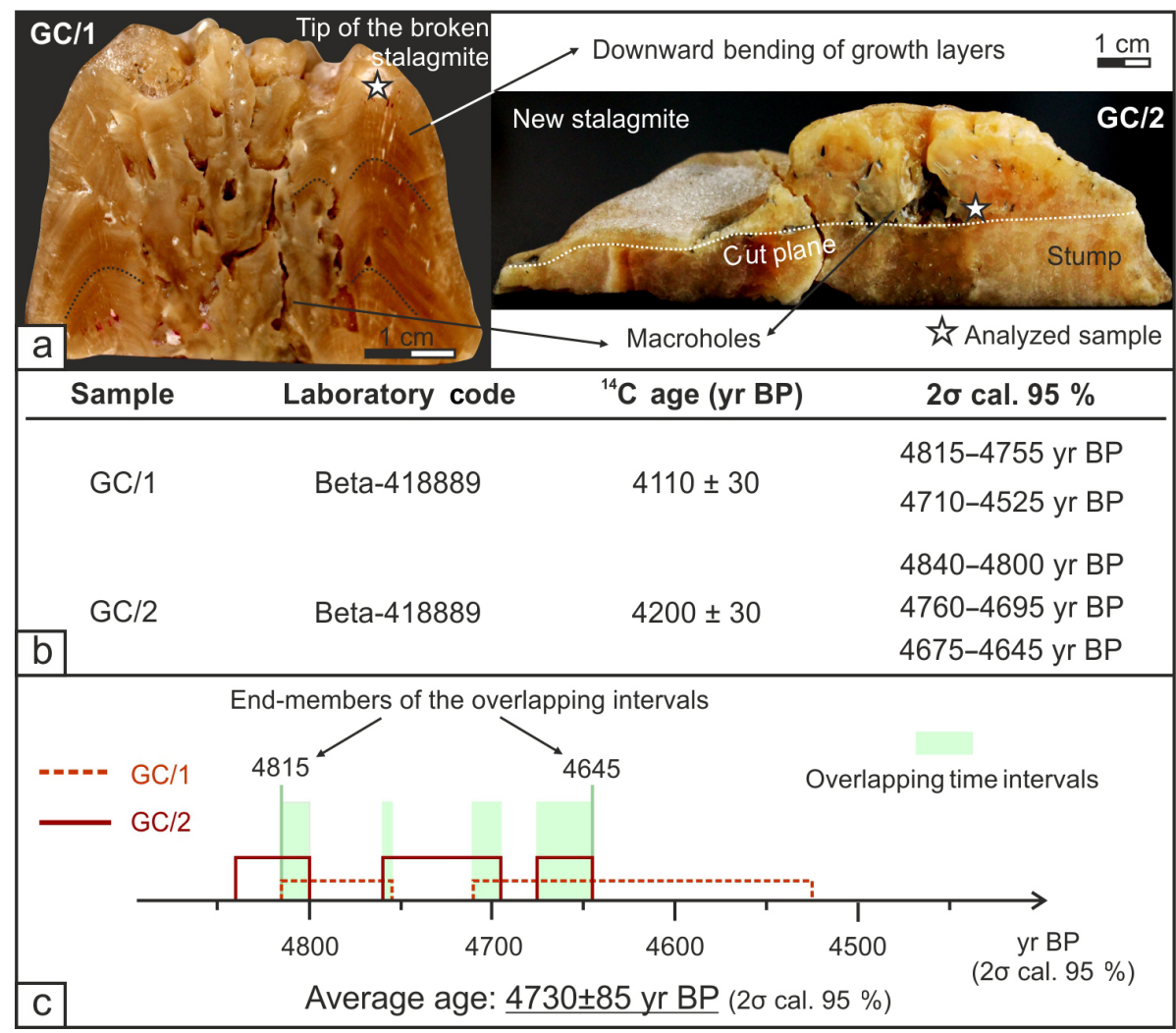

Figure 6. (a) Images of the analyzed samples GC/1 (tip of the broken stalagmite, likely pre-seismic) and GC/2 (new stalagmite growing on the stump, likely post-seismic); see sample locations in Fig. 5b. The axial section of the two samples shows a characteristic internal porous structure due to the presence of widespread syn-genetic "macroholes" (Shtober-Zisu et al., 2012), which are also responsible for the downward bending of the growth layers (marked with dotted lines in a). White stars indicate the points where material was collected for radiocarbon dating. (b) Results of the dating performed on the two samples through AMS analysis (by Beta Analytic Radiocarbon Dating Laboratory, Florida, USA). (c) Overlapping time intervals that allow for restricting the time span within which the rupture of the speleothem occurred (4730 $\pm 85 \mathrm{yr} \mathrm{BP})$.

likely 600-700 years old), in a time span strictly comparable with the age of the speleothem rupture in the Cavallone Cave (Fig. 7).

Although we cannot assess for certain whether the two events were perfectly coeval, the comparable age range of these exceptional and catastrophic events suggests that both the cave damages and the Lettopalena rock avalanche may represent the effects of a strong paleoearthquake. Therefore, we searched for paleoseismological evidence along the major seismogenic sources in the vicinity of the Maiella Massif. This evidence is represented by the SW-dipping Sulmona Fault, to the west, and the thrust faults, to the east.

Regarding the extensional domain to the west of the Maiella Massif, paleoseismological trenches excavated along the northwestern portion of the Sulmona active normal fault allowed for four paleoearthquakes to be recognized (Galli et al., 2015). One of them is corroborated in two trenches by the presence of a faulted colluvium. The ages of the involved material are included within 5580-3370 yr BP. Combining the dating coming from the two trenches, the authors defined the most probable earthquake interval to be around 4800-4300 yr BP (Galli et al., 2015). This age surprisingly matches with the speleothem and rock avalanche dating, showing a strong correspondence between speleoseismological and classical paleoseismological analyses, identifying a mid-Holocene earthquake around 4.6-4.8 kyr BP that was likely responsible for both the high cave damages found in the Cavallone Cave and the Lettopalena rock avalanche (Fig. 7a).

Moreover, faulting events with a comparable midHolocene age have been recognized along the RotellaAremogna normal fault system (composed of a set of subparallel, closely spaced fault segments: Pizzalto, Rivisondoli, Cinque Miglia and Aremogna faults; Fig. 7b; see Tesson et al., 2016, and references therein), located along the southeastern prosecution of the Sulmona Fault. Paleoseismological data collected along the Rivisondoli normal fault allowed for defining an earthquake post-dating the deposition of a paleosol dated 5415-5324/5585-5443 yr BP $(2 \sigma$ calibrated age interval obtained from the conversion of the 
$4730 \pm 50 \mathrm{yr} \mathrm{BP}{ }^{14} \mathrm{C}$ age reported in Calderoni et al., 1990, and Brunamonte et al., 1991; calculations were performed using the CALIB 7.0 software by Stuiver et al., 2016) and then overlapping the Sulmona and Cavallone Cave dating (Fig. 7). A nearly coeval paleoearthquake resulted from paleoseismological investigations along the Aremogna normal fault (D'Addezio et al., 2001; Fig. 7), where two paleosols pre-date (3735-3365 yr BC $2 \sigma$ calibrated age, corresponding to $5300-4890 \mathrm{yr} \mathrm{BP}$ ) and post-date (3735-3365 yr BC $2 \sigma$ calibrated age, corresponding to $5685-5315 \mathrm{yr} \mathrm{BP}$ ) the event, respectively (Fig. 7a).

Concerning the contractional domain to the east of the Maiella Massif, although active structures are known (e.g., de Nardis et al., 2011, and references therein), due to the scarcity of the available data we cannot assess whether a strong earthquake related to thrust faulting occurred in the same investigated time interval. Therefore, further studies are needed to deepen this issue.

\section{Discussion and conclusions}

The use of speleotectonics for the recognition of paleoearthquakes is highly debated in the literature both because there are many possible breakdown causes that must be discounted (e.g., Gilli, 2005) and because the required conditions to break speleothems, in terms of speleothems vulnerability and seismic input, are still unclear (e.g., Cadorin et al., 2001; Lacave et al., 2004). On the other hand, peculiar features, recognized in many caves worldwide, have been often linked to earthquake damages (e.g., Postpischl et al., 1991; Ferranti et al., 1997; Lemeille et al., 1999; Delaby, 2001; Forti, 2001; Kagan et al., 2005; Šebela, 2008; Panno et al., 2009; Bábek et al., 2015; Méjean et al., 2015), although specific paleoearthquakes identified in caves have been rarely constrained by independent data outside caves (Becker et al., 2005). The speleotectonic analysis conducted in this study within the Cavallone Cave (in the most external portion of the Central Apennines) allowed for recognizing a mid-Holocene paleoearthquake and finding robust correlations with independent on-fault and off-fault data in surrounding areas. The seismic history of this region of the Apennines and the characterization of possible seismogenic sources are still debated issues, even more so because the study area remains interposed between two seismotectonic domains (extensional to the west and contractional to the east).

Many interesting features that can be associated with sudden and catastrophic events have been recognized in the Cavallone Cave. In any case, because we cannot select only one cause for the analyzed broken speleothem, we must eliminate all other possibilities. Large glacial intrusions in the Cavallone Cave can be excluded since the climate around 5500$4500 \mathrm{yr} \mathrm{BP}$ is considered a warm period (e.g., Walker et al., 2012, and references therein), as also suggested by the presence of Quercus ilex discovered within the Lettopalena rock avalanche deposit dated by Paolucci et al. (2001), indicating the presence of an evergreen oak forest and Mediterranean climate conditions in the cave surroundings. Moreover, the dated stalagmite is located quite far from the entrance of the cave, where the ice could not have acted.

Fracturing due to catastrophic floods can also be excluded because there is no evidence of impacts on the concretions and related deposits. Moreover, falling azimuths of speleothems are clustered in two directions and the fallen tips of the stalagmites match with the stumps and lie uphill in their vicinity, suggesting the absence of transport linked to hydrodynamic floods or ice.

Most examples of the standing broken stalagmites were found on sub-horizontal cave ground, suggesting that their deformation is not related to slope instability or sediment creep. An exception can be found within the first branch of the conduit (Galleria della Devastazione), where the presence of meter-scale broken concretions, resting tilted toward the axis of the conduit, suggests that gravitational processes may have caused the local collapse of the floor (Fig. $3 \mathrm{~d}$ and e), which in turn could also have been triggered by a seismic event.

As the entrance of the cave is on a near-vertical cliff, more than $100 \mathrm{~m}$ high, human and animal access seems to have been unlikely at the time of the dating event. Even if it could have been possible, human and animal disturbance can be excluded for the portions of the conduit where paleoseismological analysis has been performed. These sectors are too far from the entrance $(\sim 1 \mathrm{~km})$ and, in addition, they would have been too hard to reach because of the articulate morphology of the cave ground (Fig. 2d).

Although gravitational processes can play an important role in defining the stability and configuration of the cave (as in the case of the Galleria della Devastazione; Fig. 3d and e), ceiling collapses, broken speleothems (both stalactites and stalagmites), preferential orientation of fallen stalagmites, and the absence of thin and long concretions observed in many portions of the conduit indicate that the cave also suffered from sudden deformation events likely linked to the occurrence of earthquakes. Two preferential trends of fallen tips of broken stalagmites emerge as parallel and perpendicular to the main known NW-SE-trending normal faults affecting this area of the Central Apennines. Moreover, a large number of stalagmites that resemble seismothems (Delaby, 2001; Forti, 2001) have been recognized. They are cut along subhorizontal planes, with the upper part lying close to their base and cemented on the floor and with a new speleothem generation re-growing onto the stumps. Stalagmites a few centimeters high are widespread in the cave, also growing on top of both collapsed deposits and broken speleothems, likely suggesting the occurrence of a sudden event after which concretions started to regrow. The seismothem chosen for dating (Fig. 5b) showed a rupture age around $4730 \pm 85 \mathrm{yr}$ BP (Fig. 6). Moreover, as the regrowth (and still growing) stalagmite is ca. $1.5 \mathrm{~cm}$ high and its base 


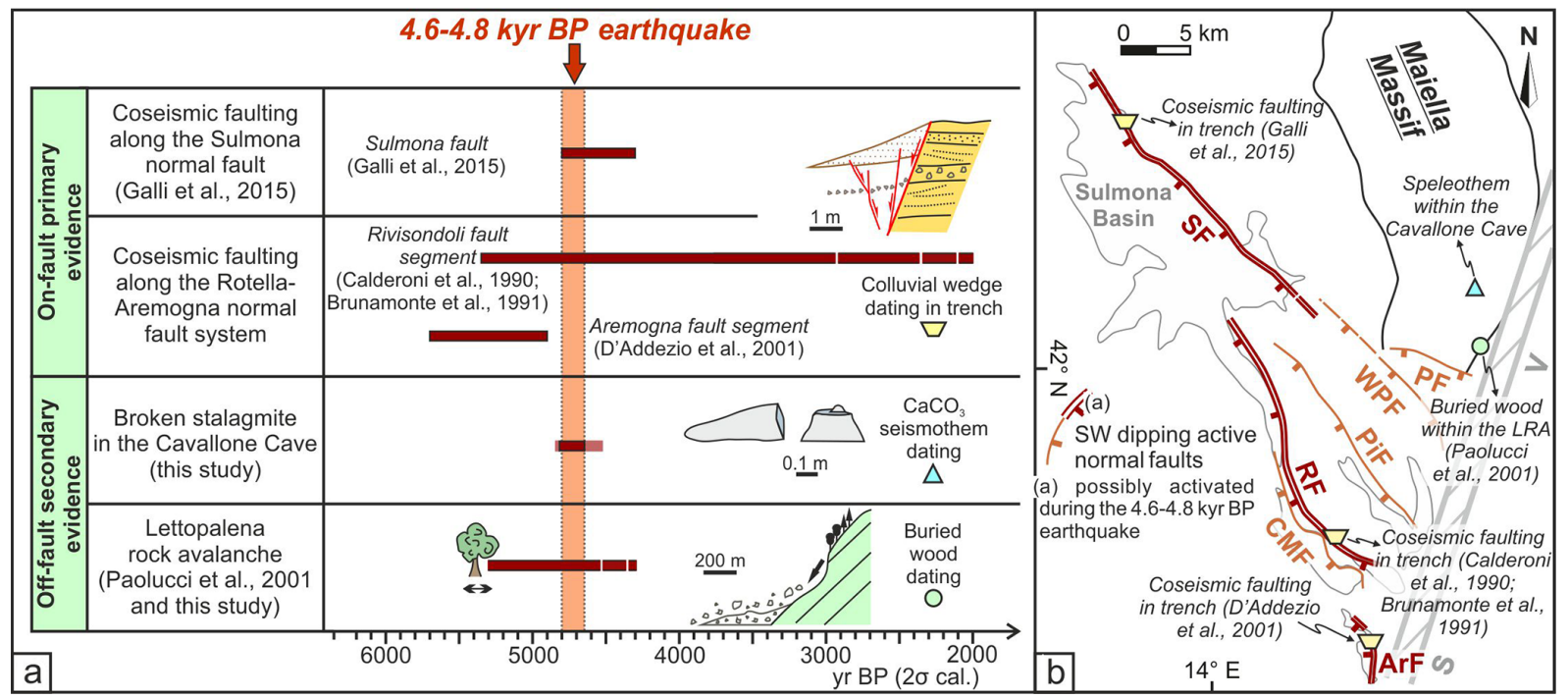

Figure 7. (a) Comparison between the ages resulting from radiocarbon dating of on-fault primary and off-fault secondary paleoseismic evidence recorded in the Maiella surroundings. One of the colluvial wedges that faulted along the Sulmona Fault reveals an earthquake within 4800-4300 yr BP (Galli et al., 2015). Paleoevents with similar ages have also been recognized along the Rivisondoli and Aremogna fault segments belonging to the Rotella-Aremogna normal fault system (Calderoni et al., 1990; Brunamonte et al., 1991; D'Addezio et al., 2001). Dating performed in this study in the Cavallone Cave (light bar) on the broken stalagmite and the new re-growing one, overlap in the range included between 4815 and $4645 \mathrm{yr}$ BP (dark bar). The wood found within the Lettopalena rock avalanche predates the rock slide event which occurred after 5445-5300 yr BP. This dating matches with around 4.6-4.8 kyr BP, constraining the age of a mid-Holocene paleoearthquake. (b) Main SW-dipping active normal faults in the vicinity of Maiella. Symbols mark comparable ages (matching around 4.6$4.8 \mathrm{kyr}$ BP) resulting from the dating of coseismic faulting along the Sulmona Fault (SF), the Rivisondoli Fault (RF) and Aremogna Fault (ArF) segments; the broken speleothem within the Cavallone Cave; and the Lettopalena rock avalanche (LRA). The synchronous activation of the Sulmona Fault with one or more normal fault segments to the south, could justify the large off-fault secondary effects recorded in the Maiella area (Cavallone Cave damages and Lettopalena rock avalanche). See the text for further explanation. PF: Palena Fault; WPF: western Porrara Fault; PiF: Pizzalto Fault; CMF: Cinque Miglia Fault; SV: Sangro-Volturno persistent structural barrier. PiF, RF, CMF and ArF all belong to the Rotella-Aremogna normal fault system.

has been dated at around 4.8-4.6 kyr BP (Fig. 6b), we can estimate a growth rate of $0.003 \mathrm{~mm} \mathrm{yr}^{-1}$ for the new stalagmite generation. The obtained value is quite different from the mean rates recognized in the literature that vary between 0.015 and $0.37 \mathrm{~mm} \mathrm{yr}^{-1}$ (e.g., White, 2007; Akgöz and Eren, 2015 , and references therein). This may be explained by variations in the growth rate of stalagmites, as well as by complexities in their structure, texture, and chemical composition (e.g., Akgöz and Eren, 2015) or by peculiar geochemical processes governing the cave environment. Moreover, the observed evidence of surface erosion and internal cavities in several stalagmites strongly suggests the occurrence of periods with a slow rate of calcite accumulation and falling-drop erosion.

Empirical relations and quantitative modeling linking dimensions of speleothems and peak ground accelerations are difficult to be applied for the dated stalagmite, as too high accelerations (PGA $>10 \mathrm{~m} \mathrm{~s}^{-2}$ ) would have been needed to break it (e.g., Cadorin et al., 2001; Lacave et al., 2004). The answer to this question can be found considering that these correlations do not take into account some parameters and conditions such as structural and chemical compo- sitional variability, presence of pre-existing discontinuities and/or anomalies within the concretions, and seismic site response (e.g., Delaby, 2001; Kagan et al., 2005), which can significantly influence the mechanic behavior and the strength of the material. In our case the analyzed stalagmites show a peculiar porous inner structure due to the presence of millimeter- to centimeter-sized holes (macroholes in Fig. 6a; Shtober-Zisu et al., 2012). We believe that the widespread distribution of these voids within a concretion could make it weaker and thus more susceptible to rupture during seismic shaking. Therefore, the ways through which speleothems convey seismic shaking still need to be understood, and more in situ and laboratory studies are needed to evaluate peak ground accelerations required to break porous speleothems.

In summary, all the data collected within the Cavallone Cave allow for the occurrence of past earthquakes to be considered plausible.

In this kind of study, the correlation of speleoseismological data with independent geological data collected outside the cave may represent the key to constrain the results (Becker et al., 2005, 2006). In our case, the dating of the seismothem analyzed in the Cavallone Cave finds very strong 
correlations with other independent phenomena that occurred in surrounding areas. Both the rock avalanche affecting the Lettopalena village (off-fault secondary earthquake evidence) and the coseismic faulting along the Sulmona normal fault (Galli et al., 2015; on-fault primary earthquake evidence) show radiocarbon ages that are strictly comparable with the dating performed on the broken stalagmite (off-fault secondary earthquake evidence; Fig. 7a). Similar ages are also obtained from paleoseismological investigations along the Rivisondoli (Calderoni et al., 1990; Brunamonte et al., 1991) and Aremogna (D'Addezio et al., 2001) normal faults (Fig. 7). Strong earthquakes associated with buried thrust fronts to the east may have also occurred in the same time interval, causing similar high damages. Although these thrusts have been proposed as alternative seismogenic sources for the $1706\left(M_{\mathrm{aw}}=6.6\right)$ and $1933\left(M_{\mathrm{w}}=5.7\right)$ Maiella earthquakes (de Nardis et al., 2011, and references therein), at present, paleoseismological and seismological data are inadequate to reliably relate them to strong earthquakes and further investigations are needed to constrain their role within the seismotectonic framework of the Maiella area.

Based on the available data we therefore suggest that the mid-Holocene paleoearthquake that occurred along the Sulmona normal fault may represent the best candidate for the causative event that produced the Cavallone Cave damages and also triggered the Lettopalena rock avalanche. Thus, following this hypothesis, the paleoearthquake can be constrained to within a time span of 4.6-4.8 kyr BP (Fig. 7a).

According to Galli et al. (2015), the 4.6-4.8 kyr BP earthquake can be considered the penultimate event for the Sulmona seismogenic structure, where the last event occurs in the 2nd century AD. Our study suggests that the 4.6$4.8 \mathrm{kyr}$ BP earthquake may have been stronger than the $M_{\mathrm{aw}}=6.32$ nd century earthquake. No other comparable large cave damages and rock avalanches are known to have occurred after the 4.6-4.8 kyr BP event at the Maiella Massif, even during the more recent strong earthquakes recorded in $1706\left(M_{\mathrm{aw}}=6.6\right)$ and in $1933\left(M_{\mathrm{w}}=5.7\right)$, although the Maiella forelimb is characterized by a near-uniform morphostructural setting (i.e., ca. 30-40 $0^{\circ}$ southeastward dipping) that by itself can favor gravitational slope instability. Furthermore, many studies indicate that, globally, more than $40 \%$ of rock avalanches that dammed streams (as in the case of the Lettopalena landslide with respect to the Aventino River; Fig. 2a) were caused by earthquake shaking (Costa and Schuster, 1991; Jibson, 1996) and have been associated, in the New Zealand area, with $M \geq 6.5$ earthquakes (Perrin and Hancox, 1992). The Sulmona Fault is potentially able by itself to produce $M$ 6.6-6.7 earthquakes (e.g., Gori et al., 2011), large enough to trigger rock avalanches such as that of Lettopalena. On the other hand, the cave damages associated with the 4.6-4.8 kyr BP earthquake seem to be the last of such an extent within the Cavallone Cave, even if the study area was affected by other strong seismic events after the 4.6-4.8 kyr BP earthquake. A larger event $(M>6.6-6.7)$ can therefore be hypothesized considering a synchronous activation of the Sulmona Fault together with one or more adjacent active fault segments (Figs. 1 and $7 b$ ). This is supported by paleoseismological investigations in trenches that allow for identification of the 4.6-4.8 kyr BP paleoearthquake along the Sulmona normal fault, in a time span comparable with the Rivisondoli (Calderoni et al., 1990; Brunamonte et al., 1991) and Aremogna paleoevents (D’Addezio et al., 2001). Moreover, Tesson et al. (2016) recognized an event along the Pizzalto normal fault segment with an age (around 1.7$1.9 \mathrm{kyr}$ ) similar to the more recent 2 nd century AD earthquake recorded along the Sulmona Fault (Galli et al., 2015). These paleoseismological data suggest that distinct fault segments of the Rotella-Aremogna fault system can be reactivated at different times and in different ways and that they can be repeatedly activated synchronously with the Sulmona normal fault (Fig. 7b). In this context, a total cumulative rupture length of about $40-50 \mathrm{~km}$ (up to the intersection with the Sangro-Volturno thrust zone; Figs. 1 and $7 \mathrm{~b}$ ) could have occurred during the 4.6-4.8 kyr BP event, likely producing a $M \sim 7$ earthquake, according to scaling relationships relating surface rupture length vs. magnitude (e.g., Wells and Coppersmith, 1994). Therefore, the synchronous activation of the Sulmona Fault together with adjacent fault segments to the southeast may explain both the higher magnitude of the resulting earthquake and why large off-fault secondary effects have been recorded in the southern Maiella area (i.e., Lettopalena rock avalanche and broken stalagmites observed at the Cavallone Cave). Nevertheless, further paleoseismological studies are needed to constrain the exact length of the surface rupture trace, the possible associated magnitude, the relations between adjacent seismogenic faults, and the modes and times of their synchronous activation. The way through which adjacent seismogenic structures interact is, at present, one of the main issues for seismically active regions such as the Apennines, where the August-October 2016 seismic sequence also showed complex deformation and rupture patterns involving distinct active normal fault segments (e.g., Pucci et al., 2016).

In conclusion, this study compares on-fault primary and off-fault secondary effects related to a single paleoevent, showing a strong correspondence between speleoseismological and classical paleoseismological analyses. Our observations indicate that major coseismic off-fault secondary effects recorded in the external zone of the Central Apennine chain (i.e., at the transition zone between inner postorogenic extension and outer chain/foreland deformation) are likely ascribed to seismogenic normal faults which are capable of producing $M \leq 7$ earthquakes, instead of contractional structures capable of $M \leq 6$ events. This is corroborated by the historical seismicity of the Central-Northern Apennines, which shows that the major earthquake hazard in the Maiella region is linked to normal faulting (e.g., Working Group CPTI, 2004; Rovida et al., 2011). Nevertheless, it should be noted that, at present, due to the scarcity of pa- 
leoseismological data, the seismic potential associated with buried contractional seismogenic sources has still not been revealed, and further studies are needed to constrain both the seismogenic structures responsible for other events, such as those of 1706 and 1933, and the seismic hazard associated with this transitional zone.

Competing interests. The authors declare that they have no conflict of interest.

Acknowledgements. We would like to thank the Speleo Club Chieti, the municipality of Taranta Peligna and the Parco Nazionale della Maiella for supporting this study and providing the map of the Cavallone Cave. We are grateful to the tourist guides of the Cavallone Cave; to Raffaele Madonna for availability and logistics; to Pierpaolo Ciuffi and Simone D'Agostino for their help in data collection; to Paolo Forti, Ezio Burri and Jo De Waele for the useful discussions in the cave; and to Gabriele Scarascia Mugnozza, Gianluca Bianchi Fasani, Silvano Agostini and the Museo di Palena, who helped us with recovering and dating the wood sample. The constructive review by Alessandro Maria Michetti allowed for improvements to the quality of the manuscript and is gratefully acknowledged. We also thank Luigi Ferranti and an anonymous reviewer for their comments and suggestions. We dedicate this work to the memory of our colleague Paolo Scandone, one of the greatest experts in Apennines geology and a lover of Maiella. This research was financially supported by the Italian Ministry for Education, University and Research (MIUR) (ex $60 \%$ grants to Alberto Pizzi).

Edited by: F. Rossetti

Reviewed by: A. M. Michetti, L. Ferranti, and one anonymous referee

\section{References}

Accotto, C., Coscarelli, F., Malerba, E., Palazzin, G., and Festa, A.: Geological Map of the Aventino River Valley (Eastern Majella, Central Italy), Journal of Maps, 10, 584-599, doi:10.1080/17445647.2014.899524, 2014.

Akgöz, M. and Eren, M.: Traces of earthquakes in the caves: Sakarlak Ponor and Kepez Cave, Mersin, (southern Turkey), J. Cave Karst Stud., 77, 63-74, doi:10.4311/2013ES0120, 2015.

Bábek, O., Briestenský, M., Přecechtělová, G., Štěpančíková, P., Hellstrom, J. C., and Drysdale, R. N.: Pleistocene speleothem fracturing in the foreland of the Western Carpathians: a case study from the seismically active eastern margin of the Bohemian Massif, Geol. Q., 59, 491-506, doi:10.7306/gq.1225, 2015.

Barchi, M., Galadini, F., Lavecchia, G., Messina, P., Michetti, A.M., Peruzza, L., Pizzi, A., Tondi, E., and Vittori, E.: Sintesi delle conoscenze sulle faglie attive in Italia Centrale: parametrizzazione ai fini della caratterizzazione della pericolosità sismica, CNR-Gruppo Nazionale per la Difesa dai Terremoti, Roma, 62 pp., 2000.
Becker, A., Ferry, M., Monecke, K., Schnellmann, M., and Giardini, D.: Multiarchive paleoseismic record of late Pleistocene and Holocene strong earthquakes in Switzerland, Tectonophysics, 400, 153-177, doi:10.1016/j.tecto.2005.03.001, 2005.

Becker, A., Davenport, C. A., Eichenberger, U., Gilli, E., Jeannin, P. Y., and Lacave, C.: Speleoseismology: A critical perspective, J. Seismol., 10, 371-388, doi:10.1007/s10950-006-9017-z, 2006.

Becker, A., Häuselmann, P., Eikenberg, J., and Gilli, E.: Active tectonics and earthquake destructions in caves of northern and central Switzerland, Int. J. Speleol., 41, 35-49, doi:10.5038/1827806X.41.1.5, 2012.

Bianchi Fasani, G., Di Luzio, E., Esposito, C., Evans, S. G., and Scarascia Mugnozza, G.: Quaternary catastrophic rock avalanches in the Central Apennines (Italy): Relationships with inherited tectonic features, gravity-driven deformations and the geodynamic frame, Geomorphology, 211, 22-42, doi:10.1016/j.geomorph.2013.12.027, 2014.

Brunamonte, F., Michetti, A. M., Serva, L., and Vittori, E.: Evidenze paleosismologiche nell'Appennino Centrale ed implicazioni neotettoniche, in: Studi preliminari all'acquisizione dati del profilo CROP11 Civitavecchia-Vasto, edited by: Tozzi, M., Cavinato, G. P., and Parotto, M., Studi Geologici Camerti, Università degli studi di Camerino, Camerino, Italy, 2, 265-270, 1991.

Butler, R. W. H., Tavarnelli, E., and Grasso, M.: Structural inheritance in mountain belts: an Alpine-Apennine perspective, J. Struct. Geol., 28, 1893-1908, doi:10.1016/j.jsg.2006.09.006, 2006.

Cadorin, J. F., Jongmans, D., Plumier, A., Camelbeeck, T., Delaby, S., and Quinif, Y.: Modelling of speleothems failure in the Hotton cave (Belgium), Is the failure earthquake induced?, Neth. J. Geosci., 80, 315-321, 2001.

Calamita, F. and Pizzi, A.: Tettonica quaternaria nella dorsale appenninica Umbro-Marchigiana e bacini intrappenninici associati, Studi Geologici Camerti, 1, 17-25, 1992.

Calamita, F. and Pizzi, A.: Recent and active extensional tectonics in the southern umbro-marchean Apennines (central Italy), Memorie della Società Geologica Italiana, 48, 541-548, 1994.

Calamita, F., Pizzi, A., and Roscioni, M.: I "fasci" di faglie recenti ed attive di M. Vettore-M. Bove e di M. Castello-M. Cardosa (Appennino Umbro-Marchigiano), and related map "Schema strutturale dei "fasci" di faglie recenti ed attive di M. VettoreM. Bove e di M. Castello-M. Cardosa (Appennino UmbroMarchigiano), Studi Geologici Camerti, 1, 81-95, 1992.

Calamita, F., Satolli, S., Scisciani, V., Esestime, P., and Pace, P.: Contrasting styles of fault reactivation in curved orogenic belts: Examples from the Central Apennines (Italy), Geol. Soc. Am. Bull., 123, 1097-1111, doi:10.1130/B30276.1, 2011.

Calderoni, G., Lorenzoni, P., Ortolani, F., Pagliuca, S., and Serva, L.: Paleoseismological evidence at Rivisondoli, Central Apennines, Italy, Rendiconti della Società Geologica Italiana, 13, 27 32, 1990

Cardello, G. L. and Doglioni C.: From Mesozoic rifting to Apennine orogeny: The Gran Sasso Range (Italy), Gondwana Res. 27, 1307-1334, doi:10.1016/j.gr.2014.09.009, 2015.

Ceccaroni, E., Ameri, G., Gómez Capera, A. A., and Galadini, F.: The 2nd century AD earthquake in central Italy: archaeoseismological data and seismotectonic implications, Nat. Hazards, 50, 335-359, doi:10.1007/s11069-009-9343-x, 2009. 
Ciarapica, G. and Passeri, L.S.: The paleogeographic duplicity of the Apennines, Boll. Soc. Geol. Ital., 1, 67-75, 2002.

Costa, J. E. and Schuster, R. L.: Documented historical landslide dams from around the world, US Geological Survey Open-File Report, 91-239, 1-486, 1991.

Coward, M. P., De Donatis, M., Mazzoli, S., Paltrinieri, S., and Wezel, F. C.: Frontal part of the Northern Apennines fold and thrust belt in the Romagna-Marche (Italy): Shallow and deep structural styles, Tectonics, 18, 559-574, doi:10.1029/1999TC900003, 1999.

D'Addezio, G., Masana, E., and Pantosti, D.: The holocene paleoseismicity of the Aremogna-Cinque Miglia Fault (Central Italy), J. Seismol., 5, 181-205, doi:10.1023/A:1011403408568, 2001.

Delaby, S.: Palaeoseismic investigations in Belgian caves, Neth. J. Geosci. 80, 323-332, 2001.

de Nardis, R., Garbin, M., Lavecchia, G., Pace, B., Peruzza, L., Priolo, E., Romanelli, M., Romano, M.A., Visini, F., and Vuan, A.: A temporary seismic monitoring of the Sulmona area (Abruzzo, Italy) for seismotectonic purposes, B. Geofis. Teor. Appl., 52, 651-666, doi:10.4430/bgta0026, 2011.

Di Domenica, A., Bonini, L., Calamita, F., Toscani, G., Galuppo, C., and Seno, S.: Analogue modeling of positive inversion tectonics along differently oriented pre-thrusting normal faults: an application to the Central-Northern Apennines of Italy, Geol. Soc. Am. Bull., 126, 943-955, doi:10.1130/B31001.1, 2014a.

Di Domenica, A., Petricca, P., Trippetta, F., Carminati, E., and Calamita, F.: Investigating fault reactivation during multiple tectonic inversions through mechanical and numerical modeling: an application to the Central Apennines of Italy, J. Struct. Geol., 67, 167-185, doi:10.1016/j.jsg.2014.07.018, 2014b.

Di Domenica, A., Turtù, A., Satolli, S., and Calamita, F.: Relationships between thrusts and normal faults in curved belts: new insight in the inversion tectonics of the CentralNorthern Apennines (Italy), J. Struct. Geol., 42, 104-117, doi:10.1016/j.jsg.2012.06.008, 2012.

Di Luzio, E., Saroli, M., Esposito, C., Bianchi Fasani G., Cavinato G. P., and Scarascia Mugnozza G.: Influence of structural framework on mountain slope deformation in the Maiella anticline (Central Apennines, Italy), Geomorphology, 60, 417-432, doi:10.1016/j.geomorph.2003.10.004, 2004.

DISS Working Group: Database of Individual Seismogenic Sources (DISS), Version 3.2.0: A compilation of potential sources for earthquakes larger than $M 5.5$ in Italy and surrounding areas, http://diss.rm.ingv.it/diss/, Istituto Nazionale di Geofisica e Vulcanologia, doi:10.6092/INGV.IT-DISS3.2.0, 2015.

Donzelli, G.: Studio geologico della Maiella (Permesso "M. Amaro"), Rapporto Interno, Montecatini Edison, reprinted by Università degli Studi “G. d'Annunzio”, Chieti, 1998, 1969.

Ferranti, L., Improta, S., Maschio, L., and Vittori, E.: Attività tettonica recente nel Massiccio del Pollino suggerita dallo studio di speleotemi fratturati, Il Quaternario, 10, 507-512, 1997.

Ferranti, L., Pace, B., Vasta, M., Colella, A., Ramondini, M., Calcaterra, D., Di Bianco, S., Valentini, A., De Massis, J., Teodoro, P., Berardi, D., and La Rocca, N.: Evaluation of the seismogenic potential in key areas of the central and southern Apennines through analysis of speleothem vulnerability, 6th International INQUA Meeting on Paleoseismology, Active Tectonics and Archaeoseismology, Pescina, Fucino Basin, Italy, doi:10.13140/RG.2.1.4533.3928, 2015.
Festa, A., Accotto, C., Coscarelli, F., Malerba, E., and Palazzin, G.: Geology of the Aventino River Valley (eastern Majella, Central Italy), Journal of Maps, 10, 584-599, doi:10.1080/17445647.2014.899524, 2014.

Forti, P.: Seismotectonic and paleoseismic studies from speleothems: The state of the art, Geol. Belg., 4, 175-185, 2001.

Forti, P. and Postpischl, D.: Seismotectonic and paleoseismic analyses using karst sediments, Mar. Geol., 55, 145-161, doi:10.1016/0025-3227(84)90138-5, 1984.

Forti, P., Petrini, V., and Postpischl, D.: Ricostruzione di fenomeni paleosismici da strutture carsiche, Rendiconti della Società Geologica Italiana, 4, 563-569, 1981.

Frepoli, A. and Amato, A.: Contemporaneous extension and compression in the Northern Apennines from earthquake fault-plane solutions, Geophys. J. Int., 129, 368-388, doi:10.1016/S00401951(99)00265-6, 1997.

Frezzotti, M. and Giraudi, C.: L'evoluzione geologica tardopleistocenica ed olocenica del Piano di Aremogna (RoccarasoAbruzzo): Implicazioni climatiche e tettoniche, Memorie della Società Geologica Italiana, 42, 5-19, 1989.

Galadini, F. and Galli, P.: Active tectonics in the Central Apennines (Italy) - input data for Seismic Hazard Assessment, Nat. Hazards, 22, 225-270, doi:10.1023/A:1008149531980, 2000.

Galadini, F. and Galli, P.: Paleoseismology of silent faults in the Central Apennines (Italy): the Mt. Vettore and Laga Mts. faults, Ann. Geophys., 46, 815-836, doi:10.4401/ag-3457, 2003.

Galli, P., Giaccio, B., Peronace, E., and Messina, P.: Holocene paleoearthquakes and Early-Late Pleistocene slip rate on the Sulmona Fault (Central Apennines, Italy), B. Seismol. Soc. Am., 105, 1-13, doi:10.1785/0120140029, 2015.

Ghisetti, F. and Vezzani, L.: Depth and modes of PliocenePleistocene crustal extension of the Apennine (Italy), Terra Nova, 11, 67-72, doi:10.1046/j.1365-3121.1999.00227.x, 1999.

Gilli, E.: Breaking of speleothems by creeping of a karstic filling, The example of the Ribiere cave (Bouches-du-Rhone), Comptes Rendus de 1'Academie des Sciences, Serie II, Fascicule ASciences de la Terre et des Planetes, 329, 807-813, 1999.

Gilli, E.: Review on the use of natural cave speleothems as palaeoseismic or neotectonic indicators, C. R. Geosci., 337, 12081215, doi:10.1016/j.crte.2005.05.008, 2005.

Gilli, E., Levret, A., Sollogoub, P., and Delange, P.: Research on the February 18, 1996 earthquake in the caves of Saint-Paul-deFenouillet area (Pyrénées Orientales, France), Geodin. Acta, 12, 143-158, doi:10.1016/S0985-3111(00)88654-4, 1999.

Gilli, E., Boudin, F., Longuevergne, L., Florsch, N., Walch, J. J., Gomez, A., Depeyre, J., and Marie, J. C.: Neotectonics and current hydrologically-induced karst deformation. Case study of the Plateau de Calern (Alpes-Maritimes, France), Geodin. Acta, 23, 49-64, doi:10.3166/ga.23.49-64, 2010.

Gori, S., Giaccio, B., F., Galadini, Falcucci, E., Messina, P., Sposato, A., and Dramis, F.: Active normal faulting along the Mt. Morrone south-western slopes (central Apennines, Italy), Int. J. Earth Sci., 100, 157-171, doi:10.1007/s00531-009-05056, 2011.

Gori, S., Falcucci, E., Dramis, F., Galadini, F., Galli, P., Giaccio, B., Messina, P., Pizzi, A., Sposato, A., and Cosentino, D.: Deep-seated gravitational slope deformation, large-scale rock failure, and active normal faulting along Mt. Mor- 
rone (Sulmona basin, Central Italy): Geomorphological and paleoseismological analyses, Geomorphology, 208, 88-101, doi:10.1016/j.geomorph.2013.11.017, 2014.

Govoni, A., Marchetti, A., De Gori, P., Di Bona, M., Lucente, F. P., Improta, L., Chiarabba, C., Nardi, A., Margheriti, L., Agostinetti, N. P., Di Giovambattista, R., Latorre, D., Anselmi, M., Ciaccio, M. G., Moretti, M., Castellano, C., and Piccinini, D.: The 2012 Emilia seismic sequence (Northern Italy): Imaging the thrust fault system by accurate aftershock location, Tectonophysics, 622, 44-55, doi:10.1016/j.tecto.2014.02.013, 2014.

Jibson, R. W.: Using landslides for paleoseismic analysis, in: Paleoseismology, edited by: McCalpin, J. P., 8, 397-438, 1996.

Kagan, E. J., Agnon, A., Bar-Matthews, M., and Ayalon, A.: Dating large infrequent earthquakes by damaged cave deposits, Geology, 33, 261-264, doi:10.1130/G21193.1, 2005.

Lacave, C., Levret, A., and Koller, M.: Measurements of natural frequencies and damping of speleothems, Proc. of the 12th World Conference on Earthquake Engineering, Auckland, NewZealand, Paper 2118, 2000.

Lacave, C., Koller, M. G., and Egozcue, J. J.: What can be concluded about seismic history from broken and unbroken speleothems?, J. Earthquake Eng., 8, 431-455, doi:10.1080/13632460409350496, 2004.

Lacave, C., Sadier, B., Delannoy, J. J., Nehme, C., and Egozcue, J. J.: The use of speleothems to better constrain long return period seismic hazard in Lebanon, Proc. of the 15th World Conference on Earthquake Engineering, Lisboa, Portugal, Paper 354, 2012.

Lemeille, F., Cushing, M., Carbon, D., Grellet, B., Bitterli, T., Flehoc, C., and Innocent, C.: Co-seismic ruptures and deformations recorded by speleothems in the epicentral zone of the Basel earthquake, Geodin. Acta, 12, 179-191, doi:10.1016/S09853111(00)88657-X, 1999.

Méjean, P., Garduño-Monroy, V. H., Pinti, D. L., Ghaleb, B., Bouvier, L., Gomez-Vasconcelos, M. G., and Tremblay, A.: U-Th dating of broken speleothems from Cacahuamilpa cave, Mexico: Are they recording past seismic events?, J. S. Am. Earth Sci., 57, 23-31, doi:10.1016/j.jsames.2014.11.002, 2015.

Montone, P., Mariucci, M. T., and Pierdominici, S.: The Italian present-day stress map, Geophys. J. Int., 189, 705-716, doi:10.1111/j.1365-246X.2012.05391.x, 2012.

Pace, P., Di Domenica, A., and Calamita, F.: Summit LowAngle Faults in the Central Apennines of Italy: younger-onolder thrusts or rotated normal faults? Constraints for defining the tectonic style of thrust belts, Tectonics, 33, 756-785, doi:10.1002/2013TC003385, 2014.

Panno, S. V., Lundstrom, C. C., Hackley, K. C., Curry, B. B., Fouke, B. W., and Zhang, Z.: Major earthquakes recorded by Speleothems in Midwestern U.S. caves, Geol. Soc. Am. Bull., 99, 2147-2154, doi:10.1785/0120080261, 2009.

Paolucci, G., Pizzi, R., and Scarascia Mugnozza, G.: Analisi preliminare della frana di Lettopalena (Abruzzo), Memorie della Società Geologica Italiana, 56, 131-137, 2001.

Papanikolaou, I. D., Roberts, G. P., and Michetti, A. M.: Fault scarps and deformation rates in Lazio-Abruzzo, Central Italy: comparison between geological fault slip-rate and GPS data, Tectonophysics, 408, 147-176, doi:10.1016/j.tecto.2005.05.043, 2005.

Patacca, E. and Scandone, P.: Post-Tortonian mountain building in the Apennines, The role of the passive sinking of a relic lithospheric slab, in: The lithosphere in Italy, edited by: Boriani, A.,
Bonafede, M., Piccardo, G. B., and Vai, G. B., Atti dei Convegni Lincei, Accademia Nazionale dei Lincei, 80, 93-109, 1989.

Patacca, E. and Scandone, P.: Geology of the Southern Apennines, Boll. Soc. Geol. Ital., 7, 75-119, 2007.

Pérez-Lopez, R., Rodríguez-Pascua, M. A., Giner-Robles, J. L., Martínez-Díaz, J. J., Marcos-Nuez, A., Silva, P. G., Bejar, M., and Calvo, J. P.: Speleoseismology and paleoseismicity of Benis Cave (Murcia, SE Spain): coseismic effects on the 1999 Mula earthquake (mb 4.8), Geological Society of London, 316, $207-$ 216, doi:10.1144/SP316.13, 2009.

Perrin, N. D. and Hancox, G. T.: Landslide-dammed lakes in New Zealand preliminary studies on their distribution, causes and effects, in: Landslides, Glissements de terrain, edited by: Bell, D. H., Balkema, Rotterdam, 1457-1466, 1992.

Pignatti, S.: Flora d'Italia, Edagricole, Bologna, 1982.

Pizzi, A.: Faglie recenti ed attive e origine delle depressioni tettoniche, Esempi dell'Appennino umbro-marchigiano, $\mathrm{PhD}$ Thesis, Università degli Studi della Calabria, 1992.

Pizzi, A.: Plio-Quaternary uplift rates in the outer zone of the central Apennine fold-and thrust belt, Italy, Quatern. Int., 101-102, 229237, doi:10.1016/S1040-6182(02)00105-2, 2003.

Pizzi, A. and Galadini, F.: Pre-existing cross-structures and active fault segmentation in the northern-central Apennines (Italy), Tectonophysics, 476, 304-319, doi:10.1016/j.tecto.2009.03.018, 2009.

Pizzi, A. and Scisciani, V.: The May 2012 Emilia (Italy) earthquakes: preliminary interpretations on the seismogenic source and the origin of the coseismic ground effects, Ann. Geophys., 55, 751-757, doi:10.4401/ag-6171, 2012.

Pizzi, A., Calamita, F., Coltorti, M., and Pieruccini, P.: Quaternary normal faults, intramontane basins and seismicity in the UmbriaMarche-Abruzzi Apennine Ridge (Italy): contribution of neotectonic analysis to seismic hazard assessment, Boll. Soc. Geol. Ital., 1, 923-929, 2002.

Pizzi, A., Falcucci, E., Gori, S., Galadini, F., Messina, P., Di Vincenzo, M., Esestime, P., Giaccio, B., Pomposo, G., and Sposato, A.: Active faulting in the Maiella Massif (central Apennines, Italy), GeoActa, 3, 57-73, 2010.

Pondrelli, S., Salimbeni, S., Ekström, G., Morelli, A., Gasperini, P., and Vannucci, G.: The Italian CMT dataset from 1977 to the present, Phys. Earth Planet. In., 159, 286-303, doi:10.1016/j.pepi.2006.07.008, 2006.

Postpischl, D., Agostini, S., Forti, P., and Quinif, Y.: Palaeoseismicity from karst sediments: the "Grotta del Cervo" cave case study (Central Italy), Tectonophysics, 193, 33-44, doi:10.1016/00401951(91)90186-V, 1991.

Pucci, S., De Martini, P. M., Civico, R., Nappi, R., Ricci, T., Villani, F., Brunori C. A., Caciagli, M., Sapia, V., Cinti, F. R., Moro, M., Di Naccio, D., Gori, S., Falcucci, E., Vallone, R., Mazzarini, F., Tarquini, S., Del Carlo, P., Kastelic, V., Carafa, M., De Ritis, R., Gaudiosi, G., Nave, R., Alessio, G., Burrato, P., Smedile, A., Alfonsi, L., Vannoli, P., Pignone, M., Pinzi, S., Fracassi, U., Pizzimenti, L., Mariucci, M. T., Pagliuca, N., Sciarra, A., Carluccio, R., Nicolosi, I., Chiappini, M., D’Ajello Caracciolo, F., Pezzo., G., Patera, A., Azzaro, R., Pantosti, D., Montone, P., Saroli, M., Lo Sardo, L., and Lancia, M.: Coseismic effects of the 2016 Amatrice seismic sequence: first geological results, Ann. Geophys., 59, 5, doi:10.4401/ag-7195, 2016. 
Rajendran, C. P., Sanwal, J., Morell, K. D., Sandiford, M., Kotlia, B.S ., Hellstrom, J., and Rajendran, K.: Stalagmite growth perturbations from the Kumaun Himalaya as potential earthquake recorders, J. Seismol., 20, 579-594, doi:10.1007/s10950-0159545-5, 2015.

Rovida, A., Camassi, R., Gasperini, P., and Stucchi, M.: CPTI11, the 2011 version of the Parametric Catalogue of Italian Earthquakes, Istituto Nazionale di Geofisica e Vulcanologia, Milano, Bologna, doi:10.6092/INGV.IT-CPTI11, 2011.

Scisciani, V.: Styles of positive inversion tectonics in the Central Apennines and in the Adriatic foreland: implications for the evolution of the Apennine chain (Italy), J. Struct. Geol., 31, 12761294, doi:10.1016/j.jsg.2009.02.004, 2009.

Scisciani, V. and Calamita, F.: Active intraplate deformation within Adria: Examples from the Adriatic region, Tectonophysics, 476, 57-72, doi:10.1016/j.tecto.2008.10.030, 2009.

Scisciani, V., Calamita, F., Bigi, S., De Girolamo, C., and Paltrinieri, W.: The influence of syn-orogenic normal faults on Pliocene thrust system development: the Maiella structure (Central Apennines, Italy), Memorie della Società Geologica Italiana, 55, 193204, 2000.

Scisciani, V., Tavarnelli, E., and Calamita, F.: The interaction of extensional and contractional deformation in the outer zone of the central Apennines, Italy, J. Struct. Geol., 24, 1647-1658, doi:10.1016/S0191-8141(01)00164-X, 2002.

Šebela, S.: Broken speleothems as indicators of tectonic movements, Acta Carsologica, 37, 51-62, 2008.

Shtober-Zisu, N., Schwarcz, H. P., Konyer, N. B., Chow, T., and Noseworthy, M. D.: Macroholes in stalagmites and the search for lost water, J. Geophys. Res.-Earth, 117, F03020, doi:10.1029/2011JF002288, 2012.

Shtober-Zisu, N., Schwarcz, H. P., Chow, T., Omelon, C. R., and Southam, G.: Caves in caves: evolution of post-depositional macroholes in stalagmites, Int. J. Speleol., 43, 323-334, doi:10.5038/1827-806X.43.3.9, 2014.

Stucchi, M., Albini, P., Mirto, C., and Rebez, A.: Assessing the completeness of Italian historical earthquake data, Ann. Geophys., 47, 659-673, 2004.

Stuiver, M., Reimer, P. J., and Reimer, A.: CALIB 7.0, available at: http://calib.org/calib/download/, last access: 24 October 2016.
Tavarnelli, E., Butler, R. W. H., Decandia, E. A., Calamita, F., Grasso, M., Alvarez, W., and Renda, P.: Implications of fault reactivation and structural inheritance in the Cenozoic tectonic evolution of Italy, in: Geology of Italy, Special Volume of the Italian Geological Society, edited by: Crescenti, U., D’Offizi, S., Merlini S., and Sacchi, R., IGC 32, Florence 2004, Soc. Geol. It., Florence, Italy, 209-222, 2004.

Tesson, J., Pace, B., Benedetti, L., Visini, F., Delli Rocioli, M., Arnold, M., Aumaître, G., Bourlès D. L., and Keddadouche, K.: Seismic slip history of the Pizzalto fault (central Apennines, Italy) using in situ-produced ${ }^{36} \mathrm{Cl}$ cosmic ray exposure dating and rare earth element concentrations, J. Geophys. Res.-Sol. Ea., 121, 1983-2003, doi:10.1002/2015JB012565, 2016.

Tozer, R. S. J., Butler, R. W. H., and Corrado, S.: Comparing thinand thick-skinned thrust tectonic models of the Central Apennines, Italy, in: Continental collision and the tectono-sedimentary evolution of forelands, edited by: Bertotti, G., Schulmann, K., and Cloething, S. A. P. L., EGU Stephan Mueller Special Publication, 1, 181-194, Strasbourg, France, 2002.

Vittori, E., Cavinato, G. P., and Miccadei, E.: Active faulting along the northeastern edge of the Sulmona basin, central Apennines, Italy, in: Perspective in Paleoseismology, edited by: Serva, L. and Slemmons, B. D., Special Publication, 6, Association of Engineering Geologists, Sudbury, Washington, 115-126, 1995.

Walker, M. J. C., Berkelhammer, M., Björck, S., Cwynar, L. C., Fisher, D. A., Long, A. J., Lowe, J. J., Newnham, R. M., Rasmussen, S. O., and Weiss, H.: Formal subdivision of the Holocene Series/Epoch: a Discussion Paper by a Working Group of INTIMATE (Integration of ice-core, marine and terrestrial records) and the Subcommission on Quaternary Stratigraphy (International Commission on Stratigraphy), J. Quaternary Sci., 27, 649-659, doi:10.1002/jqs.2565, 2012.

Wells, D. L. and Coppersmith, K. J.: New empirical relationships among magnitude, rupture length, rupture width, rupture area, and surface displacement, B. Seismol. Soc. Am., 84, 974-1002, 1994.

White, W. B.: Cave sediments and paleoclimate, J. Cave Karst Stud., 69, 76-93, 2007.

Working Group CPTI: Catalogo Parametrico dei Terremoti Italiani, vers. 2004 (CPTI04), INGV Bologna, available at: http:// emidius.mi.ingv.it/CPTI (last access: 30 September 2016), 2004. 